Situs Jurnal : $\underline{\text { http://ejurnal.stiepancasetia.ac.id/index.php/jieb }}$

Jilid 4 Nomor 1 Maret 2018

Hal $001-013$

\title{
ANALISIS KUALITAS PELAYANAN DAN KEPERCAYAAN TERHADAP KEPUASAN MAHASISWA PADA BIRO AKADEMIK DAN KEMAHASISWAAN UNISKA MAB BANJARMASIN
}

\begin{abstract}
Siti Mardah*
Abstract: The process of service in UNISKA MAB Banjarmasin which relates to the students and the problems related to the employee itself.Need to evaluate the quality of service and trust to give satisfaction to the students. This research is done to know and analyze how big influence of service quality factor to satisfaction and influence of.Conficence factor to satisfaction.Data collecting technique was obtained by using questionnaire questionnaire which obtained $10 \%$ from 17.031 number of student of UNISKA year 2017. Analize technique used is Multiple Linear Regresi. The result of research show that service quality factor have significant effect to student satisfaction level Bureau of Academic and Student Affairs UNISKA Banjarmasin MAB.
\end{abstract}

Keywords: Quality of Service,Trust,Satisfaction

Abstrak: Proses pelayanan BAK UNISKA MAB Banjarmasin yang berhubungan dengan mahasiswa dan permasalahan-permasalahan yang berkaitan dengan pihak karyawan itu sendiri. Perlu dilakukan evaluasi terhadap kualitas pelayanan dan kepercayaan untuk memberikan kepuasan kepada mahasiswa. Penelitian ini dilakukan untuk mengetahui dan menganalisis seberapa besar pengaruh faktor kualitas pelayanan terhadap kepuasan dan pengaruh faktor kepercayaan terhadap kepuasan. Teknik pengumpulan data diperoleh dengan menggunakan angket kuesioner yang didapat 10\% dari 17.031 jumlah mahasiswa UNISKA tahun 2017. Teknik analisis yang digunakan adalah Regresi Linear Berganda. Hasil penelitian menunjukkan faktor kualitas pelayanan berpengaruh signifikan terhadap tingkat kepuasan dan faktor kepercayaan juga berpengaruh signifikan terhadap tingkat kepuasan mahasiswa pada Biro Akademik dan Kemahasiswaan UNISKA MAB Banjarmasin.

Kata kunci : Kualitas pelayanan, kepercayaan, kepuasan.

\section{Latar Belakang}

Seiring meningkatnya kebutuhan masyarakat terhadap pendidikan formal, khususnya pendidikan tinggi, menjadikan perguruan tinggi sebagai wadah yang penting untuk dapat menghasilkan sumber daya manusia yang berkualitas. Sehingga untuk dapat unggul dalam persaingan itu, sebuah perguruan tinggi harus meningkatkan mutu pendidikan dan kualitas lembaga.

Sebuah lembaga dikatakan berkualitas apabila memberikan pelayanan yang berkualitas, yang dapat memenuhi kebutuhan mahasiswa akan informasi mengenai pendidikan di lembaga itu. Begitu juga sebaliknya, sebuah lembaga tidak bisa dikatakan berkualitas apabila tidak memberikan pelayanan yang baik. Dalam hal ini peneliti akan membahas ruang lingkup mengenai akademik dan kemahasiswaan, yakni menganalisis kualitas pelayanan dan kepercayaan terhadap kepuasaan mahasiswa pada Biro BAK UNISKA MAB Banjarmasin. 
Menurut Tampubolon dalam (Sufiyyah, 2011:85) menjelaskan bahwa pelayanan akademik memilki porsi yang sangat besar dalam layanan akademik. Layanan akademik merupakan layanan yang banyak berkaitan secara langsung dengan mahasiswa, sehingga perguruan tinggi dalam memberikan layanan akademik harus berusaha memahami serta memenuhi kebutuhan mahasiswa dan berakhir pada persepsi mahasiswa.

Pada dasarnya, tujuan dari administrasi akademik adalah:

1. Membentuk manajemen yang baik

2. Mendorong produktivitas kerja

3. Memaksimalkan pemanfaatan SDM dan sumber daya lain (uang, material, metode) secara terpadu.

Dengan diterapkannya hal tersebut maka tujuan yang diharapkan dalam administrasi akademik akan tercapai. Menurut Philip Koler (M. Joko Triono, 2012:5) terdapat lima unsur dalam kualitas pelayanan yang dapat dirincikan sebagai berikut :

1. Kepercayan atau kehandalan (Reliablity) :

2. Daya tanggapan (Responsiveness) :

3. Kayakinan (Assurance) :

4. Empati (Empathy) :

5. Berwujud (Tangibles) :

Pada dasarnya pengertian kepuasan atau ketidakpuasan pelanggan merupakan perbedaan antara harapan dan kinerja yang dirasakan. Sedangkan menurut Philip Koler (M. Joko Triono, 2012:7) mengatakan bahwa kepuasan adalah hasil yang dirasakan oleh konsumen yang mengalami kinerja sebuah lembaga yang sesuai dengan harapannya. Konsumen merasa puas dan senang kalau harapan mereka dipenuhi, termasuk kepuasaan mahasiswa UNISKA MAB terhadap layanan administrasi akademik (BAK) yang diberikan kepada mahasiswa apakah sesuai standar atau belum, sehingga berpatokan pada masalah itu, maka peneliti melaksanakan penelitian terhadap pengaruh faktor kualitas pelayanan dan faktor kepercayaan terhadap kepuasaan mahasiswa pada Biro Akademik Kemahasiswaan UNISKA MAB Banjarmasin.

Sesuai dengan latar belakang yang telah dikemukakan, maka rumusan masalah penelitian ini adalah sebagai berikut:

1. Apakah faktor kualitas pelayanan berpengaruh terhadap kepuasan mahasiswa?

2. Apakah faktor kepercayaan berpengaruh terhadap kepuasan mahasiswa?

\section{Kajian Literatur}

Kualitas adalah suatu tingkat kesempurnaan yang diharapkan dan pengendalian atas kesempurnaan tersebut untuk memenuhi keinginan pelanggan (Wyckof dalam Tjiptono, 2004:52). Pelayanan adalah setiap tindakan atau perbuatan yang dapat ditawarkan oleh suatu pihak kepada pihak yang lain, yang pada dasarnya bersifat tidak berwujud fisik dan tidak menghasilkan kepemilikan apapun. (Tjiptono dalam Sonya Mahanani). Jadi kualitas pelayanan (service quality) adalah suatu metode mengukur pelayanan mutu, artinya apakah pelayanan yang dilaksanakan disebuah organisasi tersebut memberikan kepuasan pada pemakai.

Menurut Philip Kotler terdapat 5 kriteria yang harus dimiliki oleh pelayanan yang berkualitas, atau disebut juga dengan indikator dari kualitas pelayanan yaitu:

1. Kepercayaan atau kehandalan (Reliability)

2. Daya tanggap (Responsiveness)

3. Keyakinan (Assurance)

4. Empati (Empathy)

5. Berwujud (Tangibles) 
Faktor-faktor yang juga mempengaruhi kepercayaan adalah Perceived Web Vendor Reputation dan Perceived Web Site Quality. Menurut Khotler (Dalam Tjiptono, 2005:336) ada 4 (empat) metode yang banyak digunakan dalam mengukur kepuasan pelanggan, yaitu :

1. Sistem Keluhan dan Saran

2. Ghost Shopping

3. Lost Customer Analysis

4. Survei Kepuasan Pelanggan

Jadi menurut Gerson (2001) menyatakan bahwa kepuasan pelanggan (customer satifaction) adalah suatu tingkatan dimana perkiraan kinerja produk/jasa sesuai dengan harapan pembeli. Pertama, penelitian yang diakukan oleh Yasmaniar (2008) dengan judul "Analisis Pengaruh Kualitas Pelayanan terhadap Kepuasan Debitur Modal Kerja dengan Kepercayaan sebagai Variabel Intervening pada PT. Bank Central Asia Kantor Cabang Solo, Tbk." Alat analisis yang digunakan adalah SEM. Hipotesisinya yang sesuai dengan penelitian adalah $\mathrm{H}_{1}$ yaitu "Terdapat pengaruh kualitas pelayanan terhadap kepuasan" dan $\mathrm{H}_{2}$ yaitu "Terdapat pengaruh kepercayaan terhadap kepuasan”. Kedua, penelitian yang dilakukan oleh Wijayanti (2012) dan Winahyuningsih (2013). Hipotesis yang sesuai yaitu $\mathrm{H}_{4}$ : "Persepsi terhadap trust mempengaruhi kepuasan." Hasil penelitian menunjukkan bahwa kepercayaan secara positif berpengaruh terhadap kepuasan (hipotesis diterima). Persamaan penelitian ini terletak pada alat analisis yang digunakan yang digunakan dan hipotesis yang diajukan (sesuai dengan Hipotesis 2).

Berdasarkan pada teori-teori yang telah dikemukakan diatas serta penelitian yang dilakukan oleh Handayani (2007), Yasminar (2008), Akbar \& Parvez (2009), bahwa kualitas pelayanan berpengaruh terhadap kepuasan, maka dapat disusun hipotesis sebagai berikut:

$\mathrm{H}_{1} \quad$ : Faktor kualitas pelayanan diduga berpengaruh terhadap tingkat kepuasan

Berdasarkan pada teori yang telah dikemukakan sebelumnya serta penelitian yang dilakukan oleh Yasminar (2008) dan Chang, Chen \& Lan (2013) bahwa kepercayaan berpengaruh terhadap kepuasan, maka dapat disusun hipotesis sebagai berikut:

$\mathrm{H}_{2}$ : Faktor kepercayaan diduga berpengaruh terhadap kepuasan.

\section{Metode Penelitian}

Berdasarkan hasil kajian pustaka dan hasil penelitian terdahulu mengenai pengaruh faktor kualitas pelayanan terhadap kepuasan pelanggan, maka dikembangkan model dasar sebagai kerangka konseptual, seperti ditunjukkan pada Gambar 1.

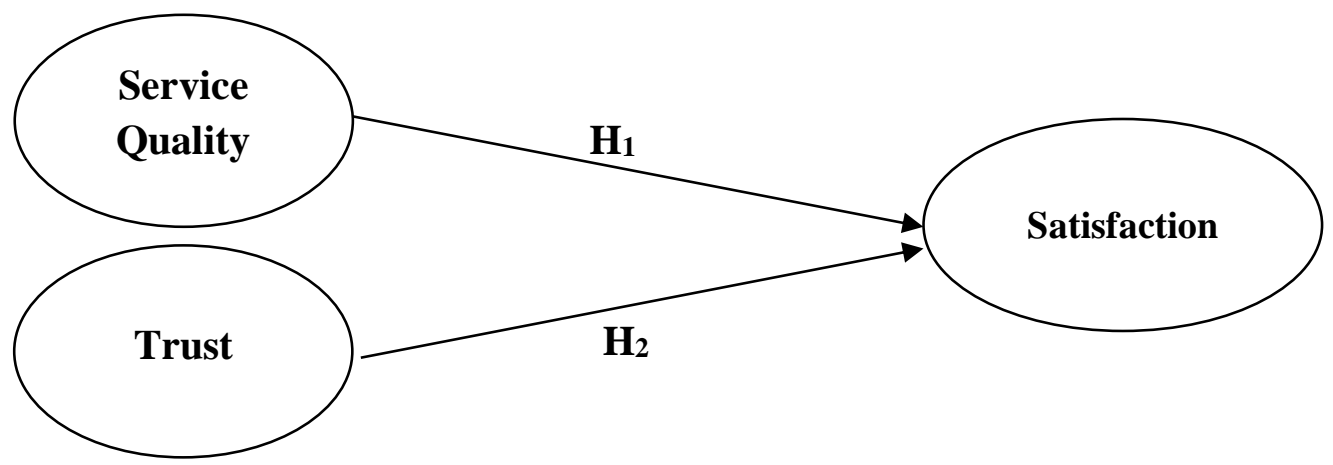

Gambar 1. Model Dasar Penelitian 
Apabila Gambar 1 yang merupakan kerangka dasar penelitian di atas diuraikan lebih lanjut dengan menampilkan indikator dari setiap variabel yang membentuk kualitas pelayanan maupun indikator dari kepercayaan maka akan nampak seperti pada Gambar 2.

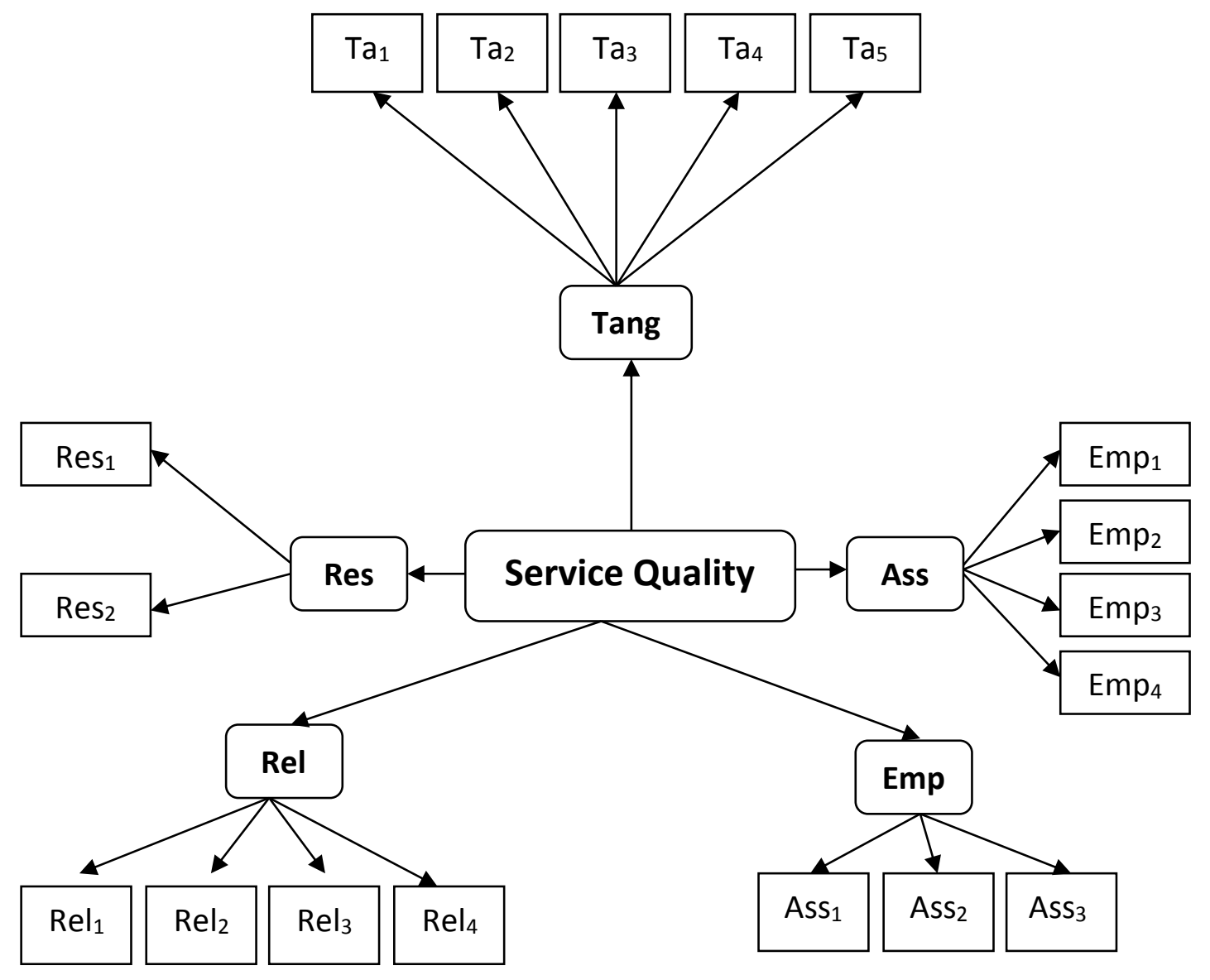

Gambar 2. Variabel Service Quality dan Indikator Tangibles, Reliability, Responsiveness, Assurance, Emphaty

Dari Gambar 2 dapat dijabarkan lebih lanjut sebagai berikut ini :

1. Service quality memiliki lima variabel yaitu tangibles, reliability, responsiveness, assurance, dan emphaty.

2. Kepercayaan (trust) memiliki tiga indikator yaitu benevolence $\left(\operatorname{Tr}_{1}\right)$, honesty $\left(\operatorname{Tr}_{2}\right)$ dan competence $\left(\operatorname{Tr}_{3}\right)$.

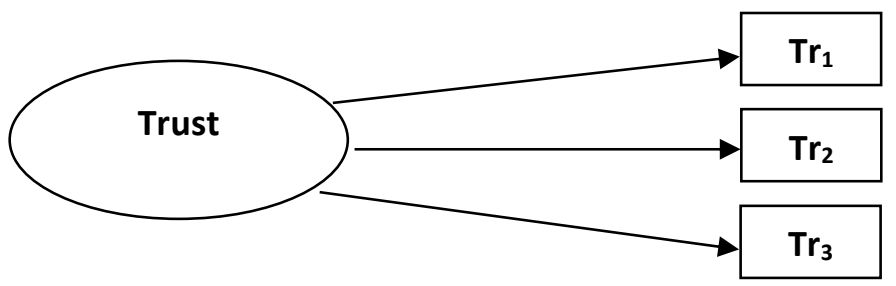

Gambar 3. Indikator Trust 
3. Kepuasan memiliki tiga indikator yaitu kepuasan terhadap pelayanan yang diberikan $\left(\mathrm{S}_{1}\right)$, kepuasan terhadap fasilitas yang disediakan $\left(\mathrm{S}_{2}\right)$, kesediaan merekomendasikan kepada orang lain $\left(\mathrm{S}_{3}\right)$.

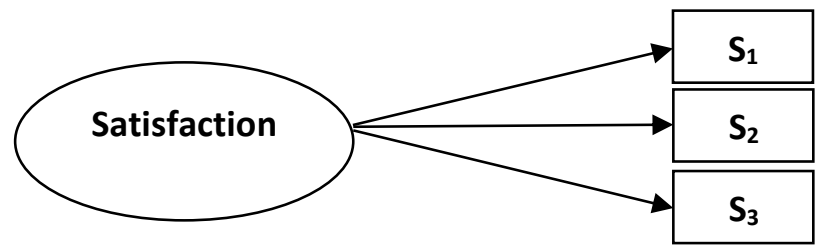

\section{Gambar 4. Indikator Satisfaction}

Penelitian ini dilakukan di kampus Universitas Islam Kalimantan (UNISKA) MAB Banjarmasin unit kerja Biro Administrrasi dan Akademik (BAK). Populasi penelitian dari Sugiono dalam Abdurrahman (2005) memberi pengertian bahwa populasi adalah generalisasi yang terdiri dari obyek yang mempunyai kualitas dan karakteristik tertentu yang ditetapkan oleh peneliti untuk dipelajari kemungkinan ditarik kesimpulannya. Sedangkan menurut Sugiono dalam Abdurrahman (2005) menyatakan sampel adalah sebagian dari jumlah dan karakteristiknya yang dimiliki oleh populasi tersebut dan jika populasinya besar dan peneliti tidak mungkin mempelajari semua yang ada pada populasi.

Jumlah populasi yang diambil untuk menentukan ukuran sampel ialah mahasiswa yang aktif tahun 2017, sesuai dengan sumber BAK UNISKA MAB Banjarmasin. Metode pengambilan sampel yang digunakan dalam penelitian ini adalah semua sampel diambil dari anggota populasi yang dilakukan secara stratifikasi proportional random sampling dengan jumlah sampel yang akan diteliti $10 \%$ dari jumlah 17.031 mahasiswa UNISKA MAB Banjarmasin tahun 2017. Adapun rumus yang digunakan adalah rumus Slovin dalam Suharso (2009) yaitu :

$n=\frac{N}{1+N e^{2}}$

Dimana :

$\mathrm{n}$ : Ukuran sampel

$\mathrm{N}$ : Ukuran Populasi

e : Persen kelonggaran ketidaktelitian karena kesalahan pengambilan sampel yang masih dapat ditolerir/diinginkan.

Dengan menggunakan rumus di atas maka perhitungan pengambilan jumlah sampel penelitian dari populasi yang berjumlah 17.031 mahasiswa UNISKA MAB Banjarmasin tahun 2017, sumber BAK UNISKA MAB Banjarmasin adalah sebagai berikut:

$n=\frac{N}{1+N e^{2}}=\frac{17.031}{1+17.031(0,10)^{2}}=\frac{17.031}{171}=99,596$

Dari perhitungan di atas, maka jumlah sampel penelitian yang diambil adalah sebanyak 100 orang mahasiswa UNISKA MAB Banjarmasin. 
Faktor yang diukur dalam penelitian ini yaitu faktor kualitas pelayanan, kepercayaan dan nilai menggunakan pertanyaan dalam bentuk kuesioner dan dibuat dalam bentuk pertanyaan dengan menggunakan skala Likett 1-4 yang diberi skor atau nilai sebagai berikut :

Sangat Tidak Setuju (STS), Tidak Setuju (TS), Setuju (S), Sangat Setuju (SS)
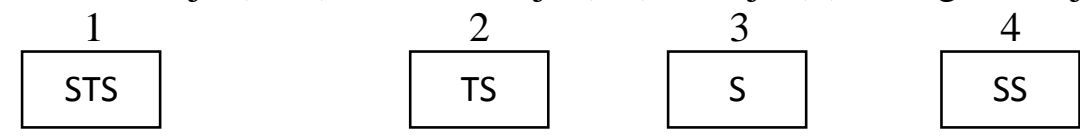

Suatu penelitian memerlukan analisis data yang digunakan untuk menjawab pertanyaanpertanyaan penelitian. Analisis data dilakukan dengan menggunakan analisis kuantitatif yang diuji dengan bantuan SPSS 22 dengan melakukan uji validitas, realibilitas, uji asumsi klasik, uji parsial, uji $\mathrm{F}$, regresi linear berganda dan korelasi untuk mencari hubungan antara variabel $\mathrm{X}$ dan variabel $\mathrm{Y}$. Teknik yang digunakan dalam menganalisis pengaruh variabel independen terhadap variabel dependen adalah Regresi Linier Berganda dengan formula

$\mathrm{Y}=\mathrm{a}+\mathrm{b} \mathrm{X}_{1}+\mathrm{b} \mathrm{X}_{3}$

\section{Hasil Penelitian dan Pembahasan}

Biro Administrasi dan akademik merupakan bidang pelayanan yang ada di Universitas Islam Kalimantan (UNISKA) MAB Banjarmasin. Biro ini menyediakan segala layanan mahasiswa yang berhubungan dengan persoalan perkuliahan. Administrasi akademik merupakan induk dari bidang pelayanan yang ada di Universitas Islam Kalimantan MAB Banjarmasin.

Kepuasan mahasiswa memang hal yang sangat penting untuk mencapai kualitas mutu dalam administrasi akademik, dan hal itu terdapat dalam layanan. Dalam penelitian ini responden seluruhnya adalah mahasiswa semester dua dan tiga, yang berarti secara umum mereka yang dijadikan sebagai responden dianggap tepat karena telah merasakan secara langsung bagaimana kualitas pelayanan yang diberikan oleh Biro Administrasi dan Akademik UNISKA MAB Banjarmasin..

Pengujian diawali dengan uji instrumen, yaitu uji validitas dan reliabilitas. Validitas adalah suatu ukuran yang menunjukkan bahwa variabel yang diukur memang benar-benar variabel yang hendak diteliti oleh peneliti (Cooper dan Schindler, dalam Zulganef, 2006). Uji validitas adalah uji yang digunakan untuk menunjukkan sejauh mana alat ukur yang digunakan dalam suatu mengukur apa yang diukur. Pengujian validitas dilakukan dengan menggunakan tingkat kepercayaan sebesar 95\%, taraf signifikasi atau $\alpha$ sebesar 0,05 dan degree of freedom ( $\mathrm{df}=\mathrm{n}-2)$ dan nilai $\mathrm{n}$ sebanyak 100 (jumlah responden), maka diperoleh nilai df 98 sebesar 0,1966, dasar pengambilan keputusan pada validitas adalah sebagai berikut :

Jika $r_{\text {hitung }}>r_{\text {tabel }}(0,197)$, maka butir pertanyaan dianggap valid.

Jika $r_{\text {hitung }}<r_{\text {tabel }}(0,197)$, maka butir pertanyaan dianggap tidak valid.

Dan pengujian validitas untuk variabel $\mathrm{X}_{1}, \mathrm{X}_{2}$ sebagai variabel independen dan variabel Y sebagai variabel dependen adalah sebagai berikut:

1. Dengan menggunakan bantuan SPSS versi 22 maka diperoleh hasil penelitian sebagai berikut: 
Tabel 1. Uji Validitas Variabel Kualitas Pelayanan $\left(\mathbf{X}_{1}\right)$

\begin{tabular}{|c|c|c|c|c|}
\hline Pertanyaan & r $_{\text {hitung }}$ & $\mathrm{R}_{\text {tabel }}$ & Kesimpulan & Keterangan \\
\hline $\mathrm{X}_{1}$ & 0,322 & \multirow[t]{18}{*}{0,197} & $r_{\text {hitung }}>r_{\text {tabel }}$ & Valid \\
\hline $\mathrm{X}_{2}$ & 0,203 & & $r_{\text {hitung }}>r_{\text {tabel }}$ & Valid \\
\hline$X_{3}$ & 0,225 & & $r_{\text {hitung }}>r_{\text {tabel }}$ & Valid \\
\hline $\mathrm{X}_{4}$ & 0,550 & & $r_{\text {hitung }}>r_{\text {tabel }}$ & Valid \\
\hline $\mathrm{X}_{5}$ & 0,375 & & $r_{\text {hitung }}>r_{\text {tabel }}$ & Valid \\
\hline $\mathrm{X}_{6}$ & 0,552 & & $r_{\text {hitung }}>r_{\text {tabel }}$ & Valid \\
\hline $\mathrm{X}_{7}$ & 0,444 & & $r_{\text {hitung }}>r_{\text {tabel }}$ & Valid \\
\hline $\mathrm{X}_{8}$ & 0,228 & & $r_{\text {hitung }}>r_{\text {tabel }}$ & Valid \\
\hline $\mathrm{X}_{9}$ & 0,327 & & $r_{\text {hitung }}>r_{\text {tabel }}$ & Valid \\
\hline$X_{10}$ & 0,256 & & $r_{\text {hitung }}>r_{\text {tabel }}$ & Valid \\
\hline$X_{11}$ & 0,266 & & $r_{\text {hitung }}>r_{\text {tabel }}$ & Valid \\
\hline$X_{12}$ & 0,386 & & $r_{\text {hitung }}>r_{\text {tabel }}$ & Valid \\
\hline$X_{13}$ & 0,460 & & $r_{\text {hitung }}>r_{\text {tabel }}$ & Valid \\
\hline $\mathrm{X}_{14}$ & 0,364 & & $r_{\text {hitung }}>r_{\text {tabel }}$ & Valid \\
\hline $\mathrm{X}_{15}$ & 0,322 & & $r_{\text {hitung }}>r_{\text {tabel }}$ & Valid \\
\hline $\mathrm{X}_{16}$ & 0,330 & & $r_{\text {hitung }}>r_{\text {tabel }}$ & Valid \\
\hline $\mathrm{X}_{17}$ & 0,208 & & $r_{\text {hitung }}>r_{\text {tabel }}$ & Valid \\
\hline $\mathrm{X}_{18}$ & 0,408 & & $r_{\text {hitung }}>r_{\text {tabel }}$ & Valid \\
\hline
\end{tabular}

Dari pengujian validitas pada Tabel 1, diketahui seluruh butir pada pertanyaan variabel kualitas pelayanan $\left(X_{1}\right)$ dinyatakan valid karena $r_{h i t u n g}>r_{\text {tabel }}(0,197)$. Dengan menggunakan bantuan SPSS versi 22 maka diperoleh hasil penelitian sebagai berikut:

Tabel 2. Uji Validitas Variabel Kepercayaan $\left(\mathbf{X}_{2}\right)$

\begin{tabular}{|c|c|c|c|c|}
\hline Pertanyaan & $r_{\text {hitung }}$ & $\mathrm{R}_{\text {tabel }}$ & Kesimpulan & Keterangan \\
\hline $\mathrm{X}_{19}$ & 0,726 & \multirow[t]{3}{*}{0,197} & $r_{\text {hitung }}>r_{\text {tabel }}$ & Valid \\
\hline$X_{20}$ & 0,522 & & $r_{\text {hitung }}>r_{\text {tabel }}$ & Valid \\
\hline$X_{21}$ & 0,587 & & $r_{\text {hitung }}>r_{\text {tabel }}$ & Valid \\
\hline
\end{tabular}

Dari pengujian validitas di atas, diketahui seluruh butir pada pertanyaan variabel kepercayaan $\left(\mathrm{X}_{2}\right)$ dinyatakan valid karena $\mathrm{r}_{\text {hitung }}>\mathrm{r}_{\text {tabel }}(0,197)$.

Dengan menggunakan bantuan SPSS versi 22 maka diperoleh hasil penelitian sebagai berikut:

Tabel 3. Uji Validitas Variabel Kepuasan (Y)

\begin{tabular}{|c|c|c|c|c|}
\hline Pertanyaan & $\mathrm{r}_{\text {hitung }}$ & $\mathrm{R}_{\text {tabel }}$ & Kesimpulan & Keterangan \\
\hline$X_{22}$ & 0,592 & \multirow[t]{3}{*}{0,197} & $r_{\text {hitung }}>r_{\text {tabel }}$ & Valid \\
\hline$X_{23}$ & 0,446 & & $r_{\text {hitung }}>r_{\text {tabel }}$ & Valid \\
\hline$X_{24}$ & 0,680 & & $r_{\text {hitung }}>r_{\text {tabel }}$ & Valid \\
\hline
\end{tabular}

Data pengujian validitas di atas, diketahui seluruh butir pada pertanyaan variabel kepuasan (Y) dinyatakan valid karena $r_{\text {hitung }}>r_{\text {tabel }}(0,197)$.

Dasar pengambilan keputusan pada pengujian reliabilitas ini diangggap sebagai berikut:

- Jika nilai Cronbach Alpha $>r_{\text {tabel }}(0,197)$, maka butir pertanyaan dianggap Reliabel.

- Jika nilai Cronbach Alpha $<r_{\text {tabel }}(0,197)$, maka butir pertanyaan dianggap Tidak Reliabel. 
Dan pengujian Reliabilitas untuk variabel $X_{1}, X_{2}$ sebagai variabel independen dan variabel Y sebagai variabel dependen adalah sebagai berikut:

Dengan menggunakan bantuan SPSS versi 22 maka diperoleh hasil penelitian sebagai berikut:

Tabel 4. Uji Reliabilitas Variabel Kualitas Pelayanan $\left(\mathbf{X}_{1}\right)$

Reliability Statistics

\begin{tabular}{cc}
\hline Cronbach's Alpha & N of Items \\
\hline, 609 & 18 \\
\hline
\end{tabular}

Dari tabel 4, dapat disimpulkan bahwa variabel kualitas pelayanan $\left(\mathrm{X}_{1}\right)$ dinyatakan reliabel, hal tersebut dibuktikan dari hasil perhitungan yang diperoleh nilai Cronbach Alpha $(0,609)>r_{\text {tabel }}(0,197)$, maka butir pertanyaan variabel kualitas pelayanan $\left(X_{1}\right)$ dianggap Reliabel. berikut:

Dengan menggunakan bantuan SPSS versi 22 maka diperoleh hasil penelitian sebagai

Tabel 5. Uji Reliabilitas Variabel Kepercayaan $\left(\mathbf{X}_{2}\right)$

Reliability Statistics

\begin{tabular}{cc}
\hline Cronbach's Alpha & N of Items \\
\hline, 703 & 4 \\
\hline
\end{tabular}

Dari tabel 5, dapat disimpulkan bahwa variabel kepercayaan $\left(\mathrm{X}_{2}\right)$ dinyatakan reliabel, hal tersebut dibuktikan dari hasil perhitungan yang diperoleh nilai Cronbach Alpha $(0,703)>r_{\text {tabel }}$ $(0,197)$, maka butir pertanyaan variabel kualitas pelayanan $\left(\mathrm{X}_{2}\right)$ dianggap Reliabel. Dengan menggunakan bantuan SPSS versi 22 maka diperoleh hasil penelitian sebagai berikut:

Tabel 6. Uji Reliabilitas Variabel Kepuasan (Y)

Reliability Statistics

\begin{tabular}{cc}
\hline Cronbach's Alpha & N of Items \\
\hline, 658 & 4 \\
\hline
\end{tabular}

Dari tabel 6, dapat disimpulkan bahwa variabel kepuasan (Y) dinyatakan Reliabel, hal tersebut dibuktikan dari hasil perhitungan yang diperoleh nilai Cronbach Alpha $(0,658)>r_{\text {tabel }}(0,197)$, maka butir pertanyaan variabel kualitas pelayanan (Y) dianggap Reliabel.

Pengujian asumsi klasik adalah pengujian yang dilakukan untuk memenuhi asumsi regresi linear berganda. Pengujian asumsi klasik diperlukan untuk memastikan hasil analisis regresi yang digunakan terbebas dari gejala multikolinearitas, gejala heterokedestitas, dan memenuhi asumsi normalitas, sehingga regresi yang digunakan dapat menghasilkan hasil analisis yang dapat dipertanggung jawabkan dan tidak bias.

Pengujian Multikolinearitas dilakukan dengan menggunakan program SPSS V.22, berikut ini adalah nilai Variance Inflation Factor (VIF) yang dihasilkan dari pengujian Multikolinearitas dengan menggunakan bantuan SPSS V.22.

Dasar pengambilan keputusan pada pengujian Multikolinearitas ini adalah sebagai berikut:

- Jika nilai VIF > 10, maka terjadi Multikolinearitas

- Jika nilai VIF < 10, maka tidak terjadi Multikolinearitas dan pengujian Multikolinearitas untuk Variabel $\mathrm{X}_{1}, \mathrm{X}_{2}$ sebagai Variabel Independen, dan Variabel $\mathrm{Y}$ sebagai variabel dependen adalah sebagai berikut: 
Tabel 7. Pengujian Multikolinearitas

\begin{tabular}{lcc}
\hline Model & \multicolumn{2}{c}{ Collinearity Statistic } \\
\cline { 2 - 3 } 1. Kualitas Pelayanan $\left(\mathrm{X}_{1}\right)$ & Tolerence & VIF \\
\cline { 2 - 3 } 2. Kepercayaan $\left(\mathrm{X}_{2}\right)$ &, 045 & 22,100 \\
\hline
\end{tabular}

a. Dependent variabel kepuasan (Y)

Dari tabel 7, maka dapat dikatakan uji Multikolinearitas terpenuhi, hal ini tidak bias karena dilihat dari output data SPSS V.22 bahwa semua nilai VIF > 10 berarti terjadi Multikolinearitas.

Hasil pengujian normalitas pada penelitian ini dilakukan dengan menggunakan rumus uji Normalitas Kolmogorov Sminov dan uji Normal P-P Plot, dengan bantuan program SPSS 22.

Dasar pengambilan keputusan pada pengujian Normalitas ini adalah sebagai berikut :

- Jika plot-plot menunjukkan rentangan yang berada kurang lebih dalam 1 garis lurus, maka dapat dinyatakan berdistribusi normal.

- Jika plot-plot menunjukkan rentangan yang berada menyebar, maka dapat dinyatakan berdistribusi tidak normal.

Dan pengujian normalitas untuk variabel $X_{1}, X_{2}$ sebagai variabel independen, dan variabel Y sebagai variabel dependen adalah sebagai berikut:

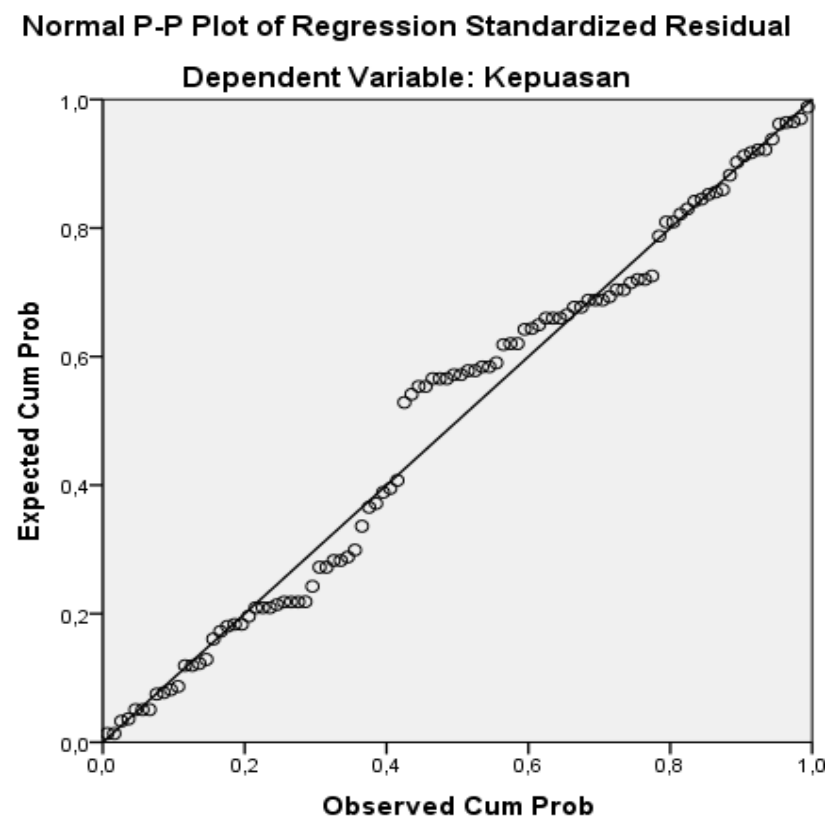

\section{Gambar 5. P-P Plot Pengujian Normalitas}

Berdasarkan gambar 5 plot-plot yang dihasilkan, menunjukkan rentangan yang berada kurang lebih dalam 1 garis lurus. Dengan demikian, maka dapat dinyatakan berdistribusi normal. Hasil pengujian Heteroskedastisitas dilakukan dengan melihat grafik plot antara nilai prediksi variabel terikat (dependen) yaitu ZPRED dengan residualnya SRESID. Deteksi ada atau tidaknya heteroskedastisitas dapat dilakukan dengan melihat ada tidaknya pola tertentu pada grafik scatterplot antara SRESID dan ZPRED dimana sumbu Y adalah Y yang telah 
diprediksi, dan sumbu $\mathrm{X}$ adalah residul (Y prediksi - Y sesungguhnya) yang telah di Studentized. Dasar pengambilan keputusan pada pengujian Heteroskedastisitas ini sebagai berikut :

- Jika ada pola tertentu, seperti titik-titik yang ada membentuk pola tertentu yang teratur (bergelombang, melebar kemudian menyempit), maka mengindikasikan telah terjadi heteroskedastisitas.

- Jika ada pola yang jelas, serta titik-titik menyebar di atas dan di bawah angka 0 pada sumbu Y, maka tidak terjadi Heteroskedastisitas.

Pengujian Heteroskedastisitas untuk variabel $X_{1}, X_{2}$ sebagai variabel independen, dan variabel Y sebagai variabel dependen sebagai berikut:

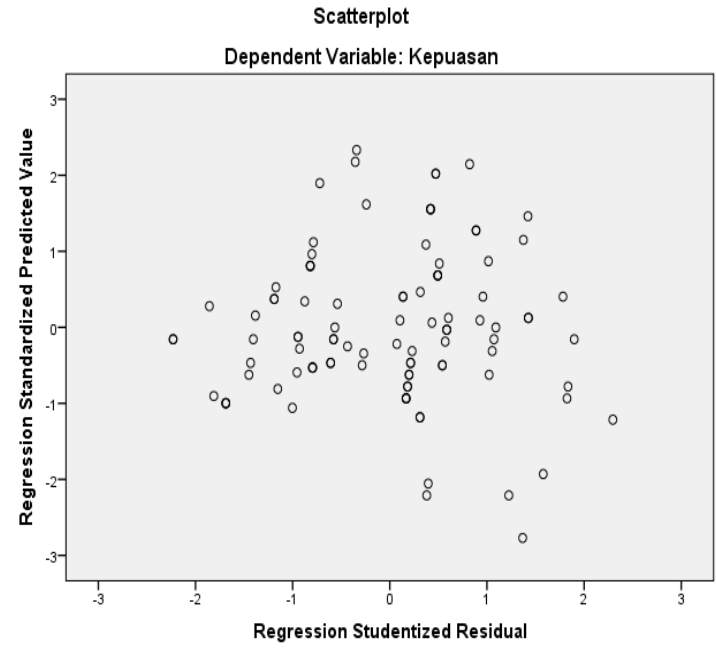

\section{Gambar 4. Scatterplot Pengujian Heteroskedastisitas}

Berdasarkan gambar 4.2 scatterplot dapat diketahui bahwa tidak terjadi heteroskedastisitas sebab tidak ada pola yang jelas serta titik-titik menyebar di atas dan di bawah angka 0 pada sumbu Y. Sehingga dapat dikatakan uji heteroskedastisitas terpenuhi.

Uji outokorelasi digunakan untuk mengetahui ada atau tidaknya penyimpangan asumsi klasik autokorelasi yaitu korelasi yang terjadi antara residual pada satu pengamatan dengan pengamatan lain pada model regresi. Prasyarat yang harus terpenuhi adalah tidak adanya autokorelasi dalam model regresi. Keputusan ada tidaknya autokorelasi adalah bila nilai Dw berada di antara dU sampai dengan 4-dU maka koefisien autokorelasi sama dengan nol. Artinya, tidak ada autokorelasi. Bila nilai Dw lebih kecil daripada dL, koefisien autokorelasi lebih besar daripada nol, artinya ada autokorelasi positif. Bila nilai Dw lebih besar dari 4-dL, koefisisen autokorelasi lebih besar daripada nol, artinya ada autokorelasi negatif.

Tabel 8. Hasil Uji Autokorelasi

Model Summary

\begin{tabular}{|c|c|c|c|c|c|}
\hline Model & $\mathrm{R}$ & $\begin{array}{c}\mathrm{R} \\
\text { Square }\end{array}$ & $\begin{array}{c}\text { Adjusted R } \\
\text { Square }\end{array}$ & $\begin{array}{c}\text { Std. Error of the } \\
\text { estimate }\end{array}$ & Durbin-Watson \\
\hline 1 &, $996^{\mathrm{a}}$ &, 991 &, 991 & 1,22184 &, 241 \\
\hline
\end{tabular}


Dengan $\mathrm{n}=98$, derajat kepercayaan $=5 \%, \mathrm{~K}=3$, maka nilai $\mathrm{DI}=1.63369$ dan $\mathrm{dU}=1.71517$ (Tabel Durban-Watson), sedangkan nilai Dw adalah sebesar 0,241. Dimana 4-dU = 4$1,71517=2,28483$. Karena nilai Dw berada diantara nilai dU dan 24-dU $(1,71517<0,241<$ 2,28483), maka dapat disimpulkan tidak terdapat autokorelasi.

Untuk menguji hipotesis digunakan alat statistik berupa uji $\mathrm{F}$ dan uji $\mathrm{t}$.

\section{Uji F}

Uji statistik F dilakukan untuk menguji apakah semua variabel bebas yang dimasukkan dalam suatu model memiliki pengaruh secara bersama-sama terhadap variabel terikat. Uji $F$ dapat dilihat pada output regresi pada tabel Anova. Dalam pengujian ini $F_{\text {hitung }}$ dibandingkan dengan $F_{\text {tabel. }}$ Apabila $F_{\text {hitung }}>F_{\text {tabel }}$ maka hipotesis diterima dengan taraf signifikan 0,05. Derajat kebebasannya adalah $(\mathrm{df})=(\mathrm{k}-1)(\mathrm{n}-\mathrm{k})$

Tabel 9. Hasil Uji F ANOVA ${ }^{a}$

\begin{tabular}{llcccc}
\hline Model & Sum of Squares & $\mathrm{dF}$ & Mean Square & $\mathrm{F}$ & Sig \\
\hline 1. Regression & 16056,190 & 2 & 8028,095 & 5377,573 &, $000^{\mathrm{b}}$ \\
Residual & 144,810 & 97 & 1,493 & & \\
Total & 16201,000 & 99 & & & \\
\hline a. & Predictors : (Constant), Kualitas pelayanan, Trust & & & \\
b. & Dependent variabel : Kepuasan & & & & \\
\end{tabular}

Nilai $\mathrm{F}$ hitung sebesar 5377,573 lebih besar dari $\mathrm{F}_{\text {tabel }}$ sebesar 3,09 dan signifikan bernilai 0.000 yang berarti sangat signifikan sehingga model dapat digunakan untuk menggambarkan hubungan antara variabel dependen dan variabel independen.

b. Uji t

Uji statistik pada dasarnya menunjukkan seberapa jauh pengaruh suatu variabel secara individual terhadap variabel dependen. Uji ini dapat dilihat dari output regresi dengan membandingkan antara $t_{\text {hitung }}$ dengan $t_{\text {tabel }}$ atau nilai signifikannya. Jika $t_{\text {hitung }}>t_{\text {tabel }}$ atau sig $\mathrm{t}<0,05$ maka hipotesis diterima dan sebaliknya. Besarnya kontribusi yang diberikan variabel bebas terhadap variabel terikatnya diketahui dari nilai koefisien determinasi parsial (r partial).

Tabel 10. Hasil uji t

\begin{tabular}{|c|c|c|c|c|c|}
\hline \multirow[t]{2}{*}{ Model } & \multicolumn{2}{|c|}{ Unstandardized Coefficients } & \multirow{2}{*}{$\begin{array}{c}\begin{array}{c}\text { Standardized } \\
\text { Coefficients }\end{array} \\
\text { Beta }\end{array}$} & \multirow[t]{2}{*}{$\mathrm{T}$} & \multirow[t]{2}{*}{ Sig } \\
\hline & B & Std. Error & & & \\
\hline 1 (Constant) & 1,041 & 1,418 & & ,734 & ,465 \\
\hline Kualitas pelayanan & 395 &, 121 & 148 & 3,274 &, 001 \\
\hline Kepercayaan & 1,586 & ,084 & 851 & 18,850 &, 000 \\
\hline
\end{tabular}

Nilai signifikasi semua komponen baik konstanta maupun variabel independen semuanya lebih kecil dari 0,05 sehingga dapat disimpulkan bahwa semua variabel independen berpengaruh signifikan terhadap variabel dependen. Persamaan model yang terbentuk:

$\mathrm{Y}=1,041+1,586 \mathrm{KP}+0,395 \mathrm{TR}$.

Dimana:

$\mathrm{Y}=$ Kepuasan; $\mathrm{KP}=$ Kualitas Pelayanan; $\mathrm{TR}=$ Trust 
Berdasarkan hasil uji hipotesis pada tabel 4.9 dan 4.10 di atas dapat dianalisis bahwa Hipotesis 1 yang menyatakan bahwa faktor kualitas pelayanan diduga berpengaruh terhadap tingkat kepuasan adalah diterima. Koefisien regresi menunjukkan nilai positif sebesar 1,586 yang artinya ada hubungan positif atau searah antara kualitas pelayanan dengan kepuasan. Artinya, apabila faktor kualitas pelayanan meningkat sebesar satu skor maka kepuasan juga meningkat sebesar 1,586 atau 158,6\%. Diinterpretasikan bahwa faktor kualitas pelayanan mempengaruhi kepuasan mahasiswa terhadap Biro Administrasi dan Akademik.

\section{Kesimpulan}

Berdasarkan kajian pustaka yang berupa uraian-uraian teori, hasil penelitian dengan penyebaran angket, serta dengan pengujian uji validitas dan uji Reliabilitas dan uji Asumsi Klasik mengunakan SPSS V.22 yaitu:

1. Dari hasil uji Validitas variabel Kualitas Pelayanan $\left(\mathrm{X}_{1}\right)$ sesuai tabel 4.1 diketahui seluruh butir pertanyaan dinyatakan valid karena $r_{\text {hitung }}>t_{\text {tabel }}(0,197)$.

2. Dari hasil uji Validitas variabel Kepercayaan $\left(\mathrm{X}_{2}\right)$, sesuai tabel 4.2 diketahui seluruh butir pertanyaan dinyatakan valid karena $r_{\text {hitung }}>t_{\text {tabel }}(0,197)$.

3. Dari hasil uji Validitas variabel Kepuasan (Y), sesuai tabel 4.3 diketahui seluruh butir pertanyaan variabel Kepuasan (Y) dinyatakan valid karena $r_{\text {hitung }}>t_{\text {tabel }}(0,197)$.

4. Dari hasil uji Reliabilitas variabel Kualitas Pelayanan $\left(\mathrm{X}_{1}\right)$, sesuai tabel 4.4, semua butir pertanyaan dianggap Reliabel.

5. Dari hasil uji Reliabilitas variabel Kepercayaan $\left(\mathrm{X}_{2}\right)$, sesuai tabel 4.5, semua butir pertanyaan dianggap Reliabel.

6. Dari hasil uji Reliabilitas variabel Kepuasan (Y), sesuai tabel 4.6, semua butir pertanyaan dianggap Reliabel.

7. Dari tabel 4.7, dapat dikatakan uji Multikolinearitas terpenuhi.

8. Dari gambar 4.1, hasil uji Normalitas menunjukan rentangan yang berada kurang lebih dalam satu garis lurus. Maka dapat dinyatakan berdistribusi normal.

9. Dari gambar 4.2, hasil uji Heteroskedastisitas menunjukkan tidak terjadi Heteroskedastisitas sebab tidak ada pola yang jelas serta titik-titik menyebar di atas dan di bawah angka 0 pada sumbu Y.

10. Dari tabel 4.8 dapat diihat hasil uji Autokorelasi yang hasilnya menunjukkan tidak terdapat Autokorelasi.

11. Dari hasil uji F dapat diihat tabel 4.9 menggambarkan hubungan antara variabel dependen dan variabel independen.

12. Dari hasil uji t dapat dilihat tabel 4.10 bahwa semua variabel independen berpengaruh signifikan terhadap variabel dependen.

\section{DAFTAR PUSTAKA}

Akbar, MM \& Parvez, N. 2009, Impact of Service Quality, Trust and Customer Salisfaction on Customer Loyality, ABAC Journal, Vol. 29. No.1

Aryani, D \& Rosinta, F. 2010, Pengaruh Kualitas Pelayanan terhadap Kepuasan Pelanggan dalam Membentuk Loyalitas Pelanggan, Jurnal Ilmu Administrasi dan Organisasi Vol. 17, No.2.

Joko Triono, Muhammad. 2012, Keputusan Mahasiswa Terhadap Layanan Administrasi Akademik Fakultas Tarbiyah IAIN WALI SONGO Semarang.

Handyani, Dwi 2007. Pengaruh Kualitas Pelayanan dan Nilai Pelanggan terhadap Kepuasan Pelanggan Hotel Patria Plaza Blitar.

Kotler, Philip. 2000. Manajemen Pemasaran. Edisi Kesepuluh, PT. Prehallindo, Jakarta. 
Santi, Apriya. 2016, Analisis Kualitas Pelayanan dan Kepercayaan terhadap Kepuasan Peserta Didik pada Lembaga Pendidikan dan Keterampilan Kharisma Banjarmasin.

Tjiptono. 2004, Pemasaran Jasa, Bayu Media Malang.

Kotler P., and Gary Armstrong. 2001. Principles of marketing. Ninth Edition, Prentice Halll, Inc, USA.

Mardah, Siti 2014. Pengaruh Motivasi dan Kompetensi terhadap Kinerja Karyawan dan Kualitas Layanan pada Rumah Makan Ayam Bakar Wongsolo.

Wijayanti. 2012, Pengaruh Relationship Marketing terhadap Kepuasan Pelanggan pada Asuransi Jiwa Bersama Bumi Putera 1912, Universitas Muhammadiyah, Purwokerto.

Walker, A. Mueller \& Helfert G. 2000, The Impact of Satisfaction, Trust and Relation Value on Commitment.

Wahyuningsih. 2013, Pengaruh Kepercayaan dan Kualitas Pelayanan terhadap Kepuasan pada Hotel Graphita Kudus.

Yasminar, VH. 2008, Analisis Pengaruh Kualitas Pelayanan terhadap Kepuasan Debitur Modal Kerja dengan Kepercayaan sebagai Intervening Variabel pada PT. BCA Kancab Solo, Tbk.

Zulganef \& Murni, A. 2008, Hubungan Kepuasan dan Kepercayaan Mahasiswa terhadap Lembaga Pendidikan Tinggi dengan Keinginan untuk Membujuk Calon Mahasiswa Melanjutkan ke Perguruan Tinggi. Jurnal Manajemen Teori dan Terapan, No.2. 